\title{
PELATIHAN KEWIRAUSAHAAN DENGAN PEMBUATAN OBAT HERBAL "JaDuLe" DI KALANGAN IBU RUMAH TANGGA
}

\author{
Nenny Syahrenny. Tegowati, Wininatin Khamimah, S.E., M.Si. \\ STIESIA SURABAYA \\ E-mail: nenny_syahrenny@stiesia.ac.id
}

\begin{abstract}
ABSTRAK
Sasaran dari pelaksanaan kegiatan Pengabdian Kepada Masyarakat (PKM) ini adalah Para Ibu Rumah Tangga. Lokasi berada di Perumahan Babatan Indah Kelurahan Babatan Kecamatan Wiyung Surabaya. Identifikasi permasalahan yang dihadapi dari kalangan Ibu Rumah Tangga adalah pada saat itu kondisi cuaca yang tidak menentu, kadang hujan dan kadang datang cuaca panas. Sehingga menyebabkan kondisi kesehatan menurun terutama anak-anak. Obat-obatan dan vitamin yang beredar di pasar harganya tidak murah mengingat para Ibu Rumah Tangga juga harus memikirkan untuk belanja sehari-hari. Tim dari PKM memberikan alternatif agar Para Ibu Rumah Tangga ini dapat menjaga kesehatan keluarganya dengan membuat obat herbal, yaitu kami beri nama JaDuLe (Jahe, Madu dan Lemon). Selain manfaatnya yang sangat besar, obat herbal terbuat dari bahan alami sehingga aman untuk kesehatan. Tujuan dari kegiatan PKM ini adalah untuk memberikan alternatif bagi Para Ibu Rumah Tangga dalam menjaga kesehatan tubuh keluarganya tanpa obat-obatan kimia. Sekaligus juga untuk melatih Para Ibu Rumah Tangga untuk berwirausaha dengan menjual obat herbal tersebut di lingkungan sekitar. Dari segi perencanaan PKM, koordinasi tim PKM dengan Para Ibu Rumah Tangga berjalan dengan baik. Rencana pelatihan sudah disepakati bersama dan masing-masing memahami tugas dan tanggung jawabnya. Tim PKM membuat materi pelatihan dan menyiapkan bahan-bahan untuk pembuatan obat herbal JaDuLe. Dari segi pelaksanaan PKM, jadwal pelatihan sudah sesuai dengan rencana yang disepakati bersama. Para Ibu Rumah Tangga paham dalam membuat obat herbal JaDuLe tersebut dan tertarik untuk mencoba rasanya. Hasil dari PKM ini Para Ibu Rumah Tangga tertarik untuk mencoba membuat sendiri dan berniat untuk menjadikan usaha.
\end{abstract}

Kata kunci: obat herbal, Ibu Rumah Tangga, JaDuLe, Jahe, Madu, Lemon

\section{PENDAHULUAN}

Kondisi cuaca belakangan yang tidak menentu, dimana kadang cuaca panas dan terkadang hujan membuat kondisi kesehatan manusia menurun. Kondisi kesehatan yang menurun tersebut terutama dirasakan sekali pada anakanak.

Orang tua pada kondisi kesehatan anak-anaknya menurun pasti berusaha susah payah untuk membuat anaknya agar tidak jatuh sakit. Jika sampai anaknya sakit, pasti orang tua terutama ibu akan berusaha mulai dari memberikan obat sampai membawa anaknya ke dokter terdekat.

Saat ini banyak obat-obatan dan vitamin yang ditawarkan di pasaran, mulai harga yang murah sampai yang termahal. Para Ibu pasti dibuat bingung dimana satu sisi ingin anggota keluarganya terutama anak-anaknya itu sehat namun di sisi lain obat-obatan dan vitamin harganya mahal terutama kondisi perekonomian sekarang. Kualitas obat dan vitamin juga dirasa masih meragukan bagi tubuh karena tidak sedikit obat dan vitamin tersebut dipalsukan oleh pihak yang tidak bertanggung jawab.

Saat ini para orang tua, terutama ibu, dituntut untuk lebih kreatif dalam kehidupan sehari-hari. Menjamin kesehatan anggota keluarganya terutama anak-anak dan menghemat pengeluaran. Saat ini banyak obat herbal yang terbuat dari bahan-bahan alami sebagai alternatif obat-obatan kimia, salah satunya adalah Jahe, Madu dan Lemon atau bisa disingkat dengan JaDuLe.

Manfaat dari Jahe, Madu dan Lemon banyak sekali terutama untuk daya tahan tubuh supaya tidak mudah terserang penyakit. Fermentasi dari ketiga bahan tersebut bermanfaat untuk Flu, Demam dan sakit lainnya. Para Ibu yang terbiasa memberikan obat bahan kimia, ramuan tersebut dapat sebagai pengganti yang alami.

Para Ibu dapat dengan mudah membuat ramuan tersebut karena bahan yang dibutuhkan relatif mudah dan terjangkau. Obat herbal "JaDuLe" ini masih belum banyak masyarakat yang mengetahui, merupakan peluang bagi ibu rumah tangga untuk membuat obat herbal tersebut dan menjualnya. Selain dapat dikonsumsi sendiri, ramuan tersebut dapat dijual kembali untuk menambah pemasukan rumah tangga. Diharapkan dengan tambahan penghasilan tersebut akan lebih sejahtera dan kesejahteraan keluarga menjadi meningkat.

\section{PENDEKATAN/METODE YANG DIGUNAKAN}

Langkah-langkah yang dilakukan oleh Tim PKM agar kegiatan dapat direalisasikan adalah sebagai berikut: 
1. Membangun kedekatan dengan Para Ibu Rumah Tangga PKK Perumahan Babatan Indah

Permasalahan yang dihadapi Para Ibu Rumah Tangga PKK Perumahan Babatan Indah juga merupakan masalah Tim PKM. Tim PKM sudah mendapatkan penyelesaian masalah tersebut sehingga ingin berbagi dengan Para Ibu Rumah Tangga PKK Perumahan Babatan Indah.

2. Menjalin kerjasama dengan pengurus PKK Perumahan Babatan Indah

Menyelesaikan permasalahan tersebut, Tim PKM melakukan kerjasama dengan pengurus PKK untuk merealisasikan program yang telah disusun. Bersama dengan pengurus PKK, menentukan tempat pelatihan dan waktu.

3. Memberikan solusi atas permasalahan yang dihadapi Tim PKM, dalam pelaksanaannya memberikan pengetahuan terlebih dahulu mengenai wirausaha dan peluang bisnisnya. Kemudian diberikan informasi mengenai manfaat bahan alami untuk menjaga kesehatan diantaranya jahe, madu dan lemon. Setelah itu dipraktikkan cara pembuatannya dan diberikan informasi berapa harga pokok produksi untuk membuat 1 resep.

Evaluasi yang dilakukan oleh tim PKM:

1. Dari segi perencanaan PKM, koordinasi tim PKM dengan Para Ibu Rumah Tangga berjalan dengan baik. Rencana pelatihan sudah disepakati bersama dan masing-masing memahami tugas dan tanggung jawabnya. Tim PKM membuat materi pelatihan dan menyiapkan bahan-bahan untuk pembuatan obat herbal JaDuLe.

2. Dari segi pelaksanaan PKM, jadwal pelatihan sudah sesuai dengan rencana yang disepakati bersama. Para Ibu Rumah Tangga paham dalam membuat obat herbal JaDuLe tersebut dan tertarik untuk mencoba rasanya.

3. Hasil dari PKM ini Para Ibu Rumah Tangga tertarik untuk mencoba membuat sendiri dan berniat untuk menjadikan usaha.

\section{PEMBAHASAN}

Pelatihan yang dilakukan oleh Tim PKM dimulai dengan koordinasi bersama Para Ibu Rumah Tangga Perumahan Babatan Indah. Tim PKM melakukan pelatihan kewirausahaan bekerjasama dengan pengurus PKK Perumahan Babatan Indah

Tim PKM dibantu 2 mahasiswa mempersiapkan materi, alat-alat dan bahan yang digunakan untuk pelaksanaan pelatihan tersebut. Alat-alat dan bahan yang digunakan antara lain toples kaca, pisau, sendok plastik, saringan, tempat memotong (telenan), jahe, madu, dan lemon.

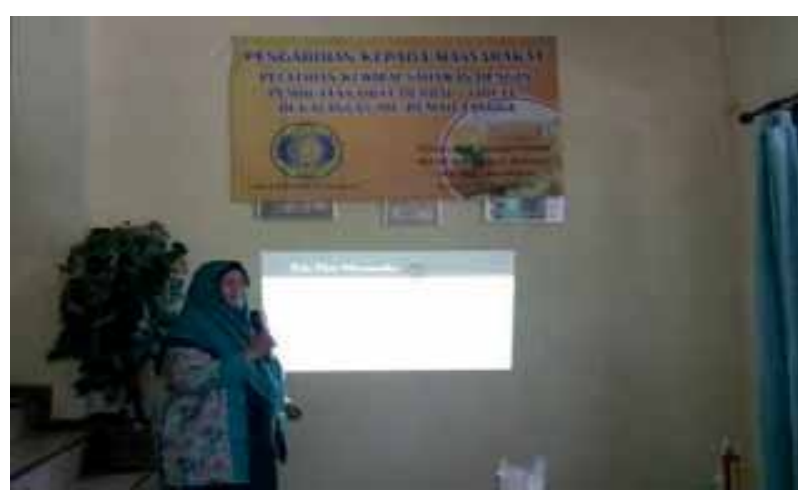

Gambar 1. Penjelasan Kewirausahaan

\section{Pelaksanaan Kegiatan}

Sesuai dengan rencana awal, pelatihan dilakukan pada tanggal 10 Mei 2018. Pelatihan diambil waktu tanggal merah dimana Para Ibu Rumah Tangga tidak sedang sibuk mengurus keluarganya yang akan beraktivitas. Pelatihan dibuka dengan menjelaskan tentang kewirausahaan dan manfaatnya dapat dilihat pada Gambar 1.

Dalam penjelasan materi tentang kewirausahaan, dijelaskan tentang arti kewirausahaan, pola pikir wirausaha. Kemudian dijelaskan pula bagaimana menjadi Ibu yang cerdas sekaligus produktif.

Kemudian dilanjutkan penjelasan mengenai cara pembuatan obat herbal JaDuLe (Jahe, Madu dan Lemon). Bahan-bahan yang dibutuhkan adalah 3-4 buah lemon, Jahe sekitar 4 ibu jari, Madu (350 - $400 \mathrm{ml}$ disesuaikan dengan wadah). Langkah-langkah pembuatannya adalah: (1) Cuci lemon dan jahe, sikat sampai bersih, untuk Lemon tidak perlu dikupas kulitnya, (2) Iris tipis lemon, (3) Jahe digeprek, (4) Masukkan jahe dan lemon dalam toples kaca dan padatkan,

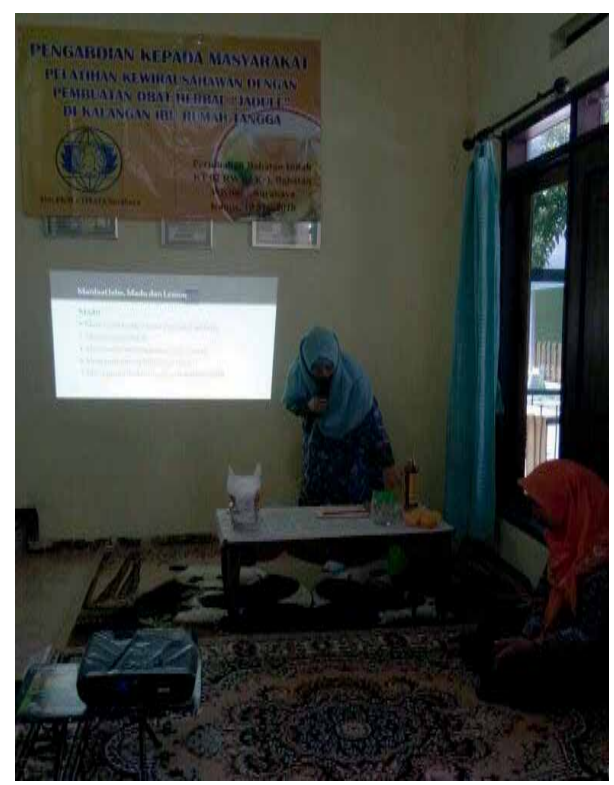

Gambar 2. Penjelasan cara pembuatan obat herbal JaDuLe 
(5) Tuang madu ke dalam toples sampai menutupi semua lemon dan jahe, (6) Tutup toples dengan rapat, (7) Diamkan di suhu ruang selama 7 hari, jauhkan dari sinar matahari, (8) Setelah hari ke 7, angkat lemon dan jahe, tiriskan, (9) Gunakan sendok kayu/ plastik untuk mengangkat lemon dan jahe, (10) Simpan cairan hasil fermentasi jahe, madu, lemon tadi dalam kulkas (Sumber: Facebook Madu Arab, 4 November 2017). Setelah itu diuraikan manfaat jahe, madu, dan lemon bagi kesehatan. Sesi terakhir pelatihan diberikan penjelasan perhitungan harga pokok produksi dan harga jual yang relevan. Berikut pada Gambar 2 merupakan penjelasan cara pembuatan obat herbal JaDuLe.

\section{PENUTUP}

\section{Kesimpulan}

Kesimpulan yang diambil dari pelaksanaan kegiatan PKM ini adalah bahwa Para Ibu Rumah Tangga khususnya PKK Perumahan Babatan Indah dapat menjaga kesehatan tubuh keluarganya secara sehat dan murah dengan membuat obat herbal JaDuLe. Para Ibu Rumah Tangga PKK Perumahan Babatan Indah dapat mengambil peluang usaha dengan menjual produk herbal yang dibuat sendiri.

\section{Saran}

Saran yang dapat diberikan dari Tim PKM adalah agar Para Ibu Rumah Tangga PKK Perumahan Babatan Indah harus menjadi Ibu yang cerdas dan produktif. Cerdas dengan memanfaatkan bahan-bahan alami dan menyehatkan untuk menjaga kesehatan tubuh keluarganya. Produktif dengan cara memanfaatkan peluang tersebut untuk usaha bisnis. Diperlukan kegiatan lebih lanjut pendampingan untuk pelaksanaan realisasi kewirausahaan.

\section{DAFTAR PUSTAKA}

Khamimah, Wininatin, Nenny Syahrenny, Tegowati. 2016. Pelatihan Menumbuhkan Jiwa Kewirausahaan di Kalangan Ibu Rumah Tangga. Lembaga Penelitian dan Pengabdian Kepada Masyarakat Sekolah Tinggi Ilmu Ekonomi Indonesia STIESIA Surabaya.

www.arah.com

www.facebook.com

www.hellosehat.com 